\title{
Glutathione-Dependent Peroxidative
}

\section{Metabolism in the Alveolar Macrophage}

\author{
Molly T. Vogt, Catherine Thomas, Charles L. Vassallo, R. E. Basford, \\ and J. Bernard L. GeE \\ From the Departments of Biochemistry and Medicine, University of Pittsburgh, \\ School of Medicine, Pittsburgh, Pennsylvania 15213
}

A B S T R A C T Phagocytosis by rabbit alveolar macrophages (AM) is accompanied by increases in $\mathrm{O}_{2}$ consumption, glucose oxidation, and $\mathrm{H}_{2} \mathrm{O}_{2}$ formation. Two aspects of the interrelations between these metabolic features of phagocytosis have been studied.

First, the following evidence indicates that glutathione, glutathione reductase, and peroxidase serve as a cytoplasmic shuttle between $\mathrm{H}_{2} \mathrm{O}_{2}$ and $\mathrm{NADPH}$-dependent glucose oxidation: (a) AM contain 5.9 m $\mu$ moles of reduced glutathione per $10^{6}$ cells and exhibit glutathione peroxidase and $\mathrm{NADPH}$-specific glutathione reductase activity; (b) oxidized glutathione potentiates NADP stimulation of glucose oxidation; (c) an artificial $\mathrm{H}_{2} \mathrm{O}_{2-}$ generating system stimulates glucose oxidation; $(d)$ the cell penetrating thiol inhibitor, $N$-ethylmaleimide diminishes glucose oxidation. This effect largely depends on inhibition of the glutathione system rather than on inhibition of either $\mathrm{H}_{2} \mathrm{O}_{2}$ formation or enzymes directly subserving glucose oxidation.

Second, three potential $\mathrm{H}_{2} \mathrm{O}_{2}$-generating oxidases have been sought. No cyanide-insensitive NADH or NADPH oxidase activity could be detected. D-amino acid oxidase activity was $0.48 \pm 0.07 \mathrm{U} / 10^{6}$ cells with $\mathrm{D}$-alanine as substrate.

\section{INTRODUCTION}

Rabbit alveolar macrophages (AM) increase $\mathrm{Q}_{2}, \mathrm{H}_{2} \mathrm{O}_{2}$ levels, and ${ }^{14} \mathrm{CO}_{2}$ production from labeled glucose during phagocytosis $(2,3)$. These responses show some similarities to those described in the polymorphonuclear leu-

Presented in part at the 1969 meeting of the Federation of American Societies for Experimental Biology (1).

Dr. Vassallo's address is Department of Medicine, Veterans Administration Hospital, Cincinatti, Ohio. Dr. Gee's address is Department of Medicine, Yale University School of Medicine, New Haven, Conn. 06510.

Received for publication 26 January 1970 and in revised form 29 July 1970. kocyte (PMN) ${ }^{1}$ by Sbarra and Karnovsky (4) and by Iyer, Islam, and Quastel (5). These studies prompted a further search for the relevant metabolic pathways in the PMN. A number of sequences have been proposed for the $\mathrm{PMN}$, which share the common element that $\mathrm{H}_{2} \mathrm{O}_{2}$ is formed from molecular $\mathrm{O}_{2}$ by an oxidase and that glucose oxidation via the pentose shunt is concurrently stimulated. They differ with respect to the specific oxidase. Four oxidases have been implicated: (a) NADH oxidase (6-8) which requires the regeneration of NADH by such mechanisms as NADPH-linked lactic acid dehydrogenase, pyridine nucleotide transhydrogenase, or glyceraldehyde-3-phosphate dehydrogenase; $(b)$ NADPH oxidase $(6,8,9)$ which requires NADPH regeneration by glucose-6-phosphate and 6-phosphogluconic acid dehydrogenases; $(c)$ white cell peroxidase (myeloperoxidase) which has been proposed as an $\mathrm{H}_{2} \mathrm{O}_{2}$-generating NADPH oxidase (10); and $(d)$ D-amino acid oxidase (11) which generates $\mathrm{H}_{2} \mathrm{O}_{2}$ via $\mathrm{FADH} \mathrm{H}_{2}$ without a direct requirement for pyridine nucleotides. The studies of Reed (12) indicated that the increased glucose oxidation is linked to $\mathrm{H}_{2} \mathrm{O}_{2}$ by a glutathione system involving glutathione peroxidase, and an NADPH-dependent glutathione reductase. The latter enzyme has recently been described in both guinea pig $(13,14)$ and human PMN (14).

The studies reported here have been designed to examine in the AM these mechanisms which have been proposed for PMN with particular reference to glutathione--dependent $\mathrm{H}_{2} \mathrm{O}_{2}$ metabolism in the AM during phagocytosis. In addition, certain oxidases potentially

${ }^{1}$ Abbreviations used in this paper: AT, aminotriazole; ATP, adenosine triphosphate; DAAO, D-amino acid oxidase; EDTA, ethylenediaminetetraacetate; FAD, flavinadenine dinucleotide; GSH, reduced glutathione; GSSG, oxidized glutathione; MPA, metaphosphoric acid; NEM, n-ethylmaleimide; NADPH, triphosphopyridine nucleotide; pCMBS, $p$-chloromercuribenzene culphonic acid; $P M N$, polymorphonuclear leukocyte; TCA, trichloroacetic acid. 
responsible for $\mathrm{H}_{2} \mathrm{O}_{2}$ generation have been sought. In this connection, it is known that the AM are critically dependent on oxidative phosphorylation. In the $\mathrm{AM}$, $\mathrm{Q}_{\mathrm{O}_{2}}$ and glucose oxidation $(2,15,16)$, ATP concentrations (16), cell viability, and particle entry $(2,16)$ are readily diminished by inhibitors of oxidative phosphorylation. However, while it is likely that much of the $\mathrm{O}_{2}$ consumption is mediated by the numerous mitochondria present in the AM (17), it has been previously demonstrated that $\mathrm{H}_{2} \mathrm{O}_{2}$ formation occurs in resting $\mathrm{AM}$ and is stimulated by phagocytosis in a quantitatively similar manner to that observed in the PMN (3). We assayed three of the aforementioned oxidases; in the previous paper (3), it was shown that AM contain no demonstrable myeloperoxidase activity, thus excluding this enzyme from consideration.

\section{METHODS}

Alveolar macrophages. The AM were harvested in Krebs-Ringer phosphate solution (KRPS) containing 5.5 $\mathrm{mM}$ glucose as described in the previous paper (3).

Glutathione reductase. Whole cell lysates were prepared by freezing (dry ice-acetone) and thawing $\left(37^{\circ} \mathrm{C}\right)$ three times a suspension of AM in KRPS $\left(20-30 \times 10^{6}\right.$ cell $\left./ \mathrm{ml}\right)$. The enzyme activity of the lysate was assayed by following the oxidation of NADPH at $340 \mathrm{~m} \mu$ in a Cary Model 14 spectrophotometer (18). To a $1.5 \mathrm{ml}$ quartz cuvette were added $0.68 \mathrm{ml}$ of $0.067 \mathrm{M}$ phosphate buffer, $\mathrm{pH} 6.6,0.03$ $\mathrm{ml}$ of $12 \mathrm{~mm} \mathrm{NADPH}$, and $0.1 \mathrm{ml}$ of $7.5 \mathrm{~mm}$ GSSG. The reaction was started by the addition of $0.2 \mathrm{ml}$ of lysate and the change in absorbancy was followed for $5 \mathrm{~min} .1 \mathrm{U}$ of activity was defined as $0.1 \mathrm{~m} \mu$ mole of NADPH oxidized/min per $10^{6}$ cells.

Glutathione peroxidase. Lysates were prepared as described for glutathione reductase. The enzyme was assayed by the method of Paglia and Valentine (19). The cuvette contained $0.85 \mathrm{ml}$ of the $0.067 \mathrm{M}$ phosphate buffer, $\mathrm{pH} \mathrm{7.0,}$ containing $5 \mathrm{~mm}$ EDTA, $0.015 \mathrm{ml}$ of $12 \mathrm{~mm}$ NADPH, $0.01 \mathrm{ml}$ GSSG reductase, $0.01 \mathrm{ml}$ of $1.125 \mathrm{M}$ sodium azide or $0.01 \mathrm{ml}$ of $0.04 \mathrm{M} \mathrm{KCN}, 0.05 \mathrm{ml}$ of $0.02 \mathrm{M} \mathrm{GSH}$, and $0.05 \mathrm{ml}$ of lysate. The reaction was initiated by the addition of $0.01 \mathrm{ml}$ of $0.022 \mathrm{M} \mathrm{H}_{2} \mathrm{O}_{2}$ and the change in absorbancy was followed at $340 \mathrm{~m} \mu$ for $5 \mathrm{~min}$. The change in absorbancy/min $(\Delta O D / \mathrm{min})$ was corrected for nonenzymatic oxidation by measuring the $\triangle \mathrm{OD}$ in a cuvette containing water in the place of the lysate. Nonenzymatic oxidation of $\mathrm{GSH}$ by $\mathrm{H}_{2} \mathrm{O}_{2}$ was the same whether water or heated lysate was used. The glutathione peroxidase activity was proportional to the protein concentration of the lysate. $1 \mathrm{U}$ of activity was defined as $1 \mathrm{~m} \mu$ mole of NADPH oxidized/min per $10^{8}$ cells.

$N A D P H-N A D$ transhydrogenase. A suspension of AM in $\operatorname{KRPS}\left(20-30 \times 10^{8}\right.$ cells $\left./ \mathrm{ml}\right)$ was homogenized in a Teflon-glass homogenizer at high speed for 30 sec. The homogenate was centrifuged at $16,000 \mathrm{~g}$ in a Sorvall RC-2 centrifuge for $10 \mathrm{~min}$. The sediment was resuspended in

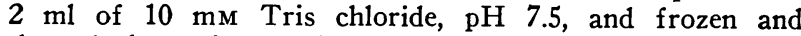
thawed three times. The enzyme activity was assayed by the method of Evans and Kaplan (20). The cuvette contained, in a final volume of $1 \mathrm{ml}, 0.5$ of $0.2 \mathrm{M}$ phosphate buffer, $\mathrm{pH} 6.5,0.1 \mathrm{ml}$ of $10 \mathrm{mM} \mathrm{KCN}, 0.5 \mathrm{ml}$ of $6 \mathrm{~mm}$ NADH, $0.05 \mathrm{ml}$ of $12 \mathrm{~mm} 3$-acetyl-pyridine NAD. The reaction was initiated by the addition of a suitable aliquot of AM extract. $1 \mathrm{U}$ of activity was defined as $0.1 \mathrm{~m} \mu \mathrm{mole}$ of acetyl-pyridine NAD reduced/min per $10^{6}$ cells.

NADPH and NADH oxidases. A suspension of AM in KRPS $\left(200 \times 10^{6}\right.$ cells $\left./ 8 \mathrm{ml}\right)$ was incubated for $30 \mathrm{~min}$ at $37^{\circ} \mathrm{C}$ in the presence and absence of latex particles with or without homologous serum. The suspensions were then centrifuged at $500 \mathrm{~g}$ for $10 \mathrm{~min}$ in a Sorvall RC-2 centrifuge. The sedimented cells were resuspended in $2 \mathrm{ml}$ of KRPS, homogenized, and freeze-thawed three times. The activity of the enzymes in the freeze-thawed homogenate was assayed by a modification of the method of Zatti and Rossi (9) with a Clark oxygen electrode (Interscience, Baltimore, Md.) and a $10 \mathrm{mv} \mathrm{X}-\mathrm{Y}$ recorder. The reaction vessel contained in a total volume of $2.0 \mathrm{ml}, 0.05 \mathrm{M}$ phosphate buffer, $\mathrm{pH} 6.0$ or $7.0,1 \mathrm{~mm} \mathrm{KCN}, 0.6 \mathrm{~mm} \mathrm{NADPH}$ or NADH, and an aliquot $(0.1-1.0 \mathrm{ml})$ of $\mathrm{AM}$ homogenate. Saponin, when added, was $1 \mathrm{mg} / \mathrm{ml}$ final concentration.

D-amino acid oxidase. AM were washed once in phosphate-buffered saline $(0.15 \mathrm{M} \mathrm{NaCl}, 0.105 \mathrm{M}$ potassium phosphate, $\mathrm{pH}$ 7.1). Cytoplasmic granules were isolated as supernatant 3 by the method of Cohn and Hirsch (21). The enzyme activity was assayed essentially as described by Dixon and Kleppe (22) using a Clark $\mathrm{O}_{2}$ electrode and a $10 \mathrm{mv} \mathrm{X}-\mathrm{Y}$ recorder. The reaction vessel contained 1.59 $\mathrm{ml}$ of $0.016 \mathrm{M}$ pyrophosphate at $\mathrm{pH} 8.3,0.5 \mathrm{ml}$ of phosphate-buffered saline at $\mathrm{pH} 7.1,0.01 \mathrm{ml}$ of $0.03 \mathrm{M}$ flavinadenine dinucleotide (FAD), and $0.2 \mathrm{ml}$ of supernatant 3 . The reaction was started by the addition of $0.2 \mathrm{ml}$ of 0.75 M D-alanine.

Glucose-6-phosphate dehydrogenase. The AM were homogenized in KRPS and the enzyme activity of the homogenate was assayed by the method of Löhr and Waller (23). The cuvette contained $0.1 \mathrm{ml}$ of $12 \mathrm{~mm}$ NADP, 0.7 $\mathrm{ml}$ of $0.05 \mathrm{M}$ triethanolamine buffer containing $5 \mathrm{~mm}$ EDTA, $\mathrm{pH} 7.5$, and $0.1 \mathrm{ml}$ of homogenate. The reaction was started by the addition of $0.1 \mathrm{ml}$ of $0.04 \mathrm{M}$ glucose- 6 phosphate. $1 \mathrm{U}$ of enzyme activity was defined as 0.1 m $\mu$ mole of NADP reduced/min per $10^{\circ}$ cells.

${ }^{14} \mathrm{CO}$ production from glucose ${ }^{14} \mathrm{C}$ and formate ${ }^{14} \mathrm{C}$. ${ }^{14} \mathrm{CO}_{2}$ production from labeled substrates using whole cells was measured as described in the previous paper (3). The effects of NADP and GSSG (Table III), an $\mathrm{H}_{2} \mathrm{O}_{2}$-generating system (Table IV), and of NADP and/or NEM (Table IX) on ${ }^{14} \mathrm{CO}_{2}$ production from glucose- $1-{ }^{14} \mathrm{C}$ were determined using cell homogenates. The AM were homogenized in KRPS (20 passes in a Teflon-glass homogenizer) before use. In a final volume of $4 \mathrm{ml}$, each flask contained the equivalent of $4 \mathrm{ml}$ of KRPS, an aliquot of AM homogenate corresponding to $10-15$ milion cells, $2 \mathrm{~mm}$ ATP, 0.3 $\mu \mathrm{Ci}$ glucose-1 $-{ }^{14} \mathrm{C}$, and where indicated in the tables, varying concentrations of NADP or NEM, $30 \mathrm{~mm}$ GSSG, 15 $\mathrm{mm}$ cystine, $37.5 \mathrm{~mm}$ DL-alanine, $50 \mu \mathrm{g}$ DAAO. The flasks were kept in an ice bath until all additions were made; incubation was for $1 \mathrm{hr}$ at $37^{\circ} \mathrm{C}$. Data for these internally controlled experiments are expressed as per cent of control. The ${ }^{14} \mathrm{CO}_{2}$ counts obtained from intact cells and homogenates were within $\pm 30 \%$ of mean counts $/ 10^{\circ}$ cells previously reported for intact cells (3).

Phagocytosis studies. Heat-killed $\left(75^{\circ} \mathrm{C}\right.$ for $\left.30 \mathrm{~min}\right)$ coagulase-negative $S$. albus were used as test particles unless otherwise stated. Particle to cell ratios were 150:1 unless otherwise specified. Phagocytosis was assessed by light microscopy of Gram-stained preparations.

Low molecular weight thiols. Lysates of AM were prepared by freezing (dry ice-acetone bath) and thawing 
$\left(37^{\circ} \mathrm{C}\right.$ water bath, $\left.5 \mathrm{~min}\right)$ three times, suspensions of $\mathrm{AM}$ (at least $30 \times 10^{\circ}$ cells) in $1 \mathrm{ml}$ of KRPS containing 1.6 mM EDTA. Three methods of deproteinization of the lysates were examined to determine optimal recovery of GSH: (a) heating for $5 \mathrm{~min}$ in a boiling water bath followed by cooling in ice, (b) $2 \%$ metaphosphoric acid (MPA) final concentration and neutralization of the supernatant fluid with $\mathrm{KOH}$ to $\mathrm{pH} 6.8$, and (c) $5 \%$ trichloroacetic acid (TCA) final concentration followed by ether extraction until the $\mathrm{pH}$ value of the aqueous phase was $\geqslant 2$. Values obtained for the GSH content of extracts of AM, or of extracts to which exogenous GSH was added, by the three methods of deproteinization were in the order heat $\geqslant$ TCA $>$ MPA. All values reported were determined on the supernatant fluid obtained after centrifugation of the heat-treated, freeze-thawed extracts for $10 \mathrm{~min}$ at $12,1000 \mathrm{~g}$ in a Sorvall RC-2 centrifuge.

Total low molecular weight thiols were determined by the nitroprusside method as described by Beutler (24). Absorbancy values were compared to those obtained with $\mathrm{GSH}$ as a standard.

Reduced and oxidized glutathione (GSH and GSSG) were determined enzymatically with glyoxalase $I$ and GSSG-reductase; respectively, as described by Klotzsch and Bergmeyer (25). The volumes of added reagents were proportionately decreased to permit the determination with $0.2 \mathrm{ml}$ of extract in a total reaction volume of $1.0 \mathrm{ml}$. Recovery of standard GSH and GSSG added to AM extracts ranged from 90 to $110 \%$.

Qualitative identification of thiol compounds in AM extracts was carried out by chromatography on Chrom-AR 500 sheets of silicic acid-impregnated glass fiber with $n$ propanol: water, $80: 20$ as solvent. Thiols were detected by a nitroprusside spray reagent described by Toennies and Kolb (26). $R_{f}$ values of the thiol components in the extract were compared with those of commercial cysteine, $\mathrm{GSH}$, and ergothioneine.

Materials. The following were obtained from Sigma Chemical Co., St. Louis, Mo.: 3-acetyl-pyridine NAD Grade I, NADPH, NADH, GSSG, GSH, ergothioneine, glucose-6-phosphate, methyl glyoxal, glyoxalase type I, D-amino acid oxidase (electrophoretically purified), GSSG reductase, Type III. Sodium formate $-{ }^{14} \mathrm{C}, 3 \mathrm{mCi} / \mathrm{mmole}$ was obtained from New England Nuclear, Boston, Mass., glucose- $1-{ }^{14} \mathrm{C} \quad(3.2 \mathrm{mCi} / \mathrm{mmole})$ and glucose-6- ${ }^{14} \mathrm{C} \quad(2.8$ $\mathrm{mCi} / \mathrm{mmole}$ ) from Nuclear Chicago. Bacto-latex particles were obtained from Difco Laboratories, Detroit, Mich., and Chrom-AR 500 silicic acid-impregnated glass fiber from Mallinkrodt Chemical Works, St. Louis, Mo. Soluene-100 was a gift from Packard Instrument Co., Downers Grove, Ill. 3-Amino-1,2,4-triazole was obtained from $\mathrm{Nu}$ tritional Biochemicals Corporation, Cleveland, Ohio and was recrystallized from ethanol.

Statistics. Student's $t$ test for paired samples was employed.

\section{RESULTS}

Enzyme activities. The activities of a number of enzymes suggested by the considerations previously outlined in the introduction are indicated in Table I. The data indicate the vigorous activity of glutathione reductase and peroxidase. The activities of the reductase and peroxidase were, respectively, 25 and 200 times more than their activities measured in the rabbit red
TABLE I

Enzyme Activities in the Alveolar Macrophage

\begin{tabular}{lrrr}
\hline & $\mathrm{n}^{*}$ & \multicolumn{2}{c}{$\begin{array}{c}\text { Units of } \\
\text { activity } \ddagger\end{array}$} \\
\hline GSSG reductase & 3 & $2.6 \pm 0.18$ \\
GSH peroxidase & 5 & $20.0 \pm 0.80$ \\
NADPH-NAD transhydrogenase & 2 & 146 & \pm 6 \\
Glucose-6-phosphate dehydrogenase & 3 & $4.0 \pm 0.31$ \\
D-Amino acid oxidase & 10 & $0.48 \pm 0.07$ \\
\hline
\end{tabular}

* n, number of experiments.

$\ddagger \mathrm{m} \mu$ moles of substrate or cosubstrate $/ \mathrm{min}$ per $10^{6}$ cells 土SEM. Complete definition of units and conditions of assay are given for each enzyme under Methods.

cell. The reductase was specific for NADPH; no activity was observed with $\mathrm{NADH}$. The activities of two other relevant enzymes are indicated in Table I. These are glucose-6-phosphate dehydrogenase and NADPHNAD transhydrogenase. The activity of the transhydrogenase was shown to be 2-3 times greater in rabbit AM than in human leukocytes (20).

Three possible $\mathrm{H}_{2} \mathrm{O}_{2}$-generating oxidases were sought. No direct oxidation of NADH or NADPH by a cyanide-insensitive NADH or NADPH oxidase could be detected. Initial attempts to measure these oxidases were patterned after the spectrophotometric method employed by Cagan and Karnovsky (7) except that $0.16 \mathrm{~mm}$ pyridine nucleotides were employed. No activity was detectable spectrophotometrically. Therefore a number of experiments were conducted employing a Clark oxygen electrode (9) which permitted the addition of higher levels of both substrate ( $0.6 \mathrm{mmole} / \mathrm{liter}$ and AM homogenate (up to $1 \times 10^{8}$ cells). No oxygen uptake was observed in the presence of cyanide when either NADH or NADPH was added to homogenates prepared from resting, phagocytosing, or saponintreated AM. However, there was definite D-amino acid oxidase activity employing $\mathrm{D}$-alanine as substrate (Table I).

Low molecular weight thiols. In view of the presence of glutathione-dependent enzyme activities, the content of low molecular weight thiol-containing compounds in the AM was measured. The values obtained, expressed as $m \mu$ moles per million cells, for total thiol, GSH, and GSSG are shown in Table II. The difference between the values reported for total thiol and GSH was determined qualitatively to be due to cysteine by chromatography on Chrom-AR 500 silicic acid-impregnated glass fibre. The absence of detectable ergothioneine on the chromatograms of the extracts of AM can be taken as an indication of minimal contamination of the AM preparations by red cells (27).

Relationship of glutathione and $\mathrm{H}_{2} \mathrm{O}$, to glucose metabolism. The existence of a glutathione system capable 
TABLE II

Low Molecular Weight Thiol Content of Rabbit Alveolar Macrophages

\begin{tabular}{lc}
\hline \multicolumn{1}{c}{ Component } & $\begin{array}{c}\text { m } \mu \text { moles } / 10^{6} \\
\text { cells } \pm \text { SEM}^{*}\end{array}$ \\
\hline Total thiol & $9.77 \pm 1.40(3)$ \\
GSH & $5.90 \pm 0.56(10)$ \\
GSSG & $0.35 \pm 0.11(10)$ \\
Total glutathione & $6.64 \pm 0.50(10)$ \\
(GSH + $2 \times$ GSSG) & \\
\hline
\end{tabular}

* Numbers in parentheses are the number of determinations.

of utilizing $\mathrm{H}_{2} \mathrm{O}_{2}$ to oxidize NADPH suggests that the levels of both GSSG and $\mathrm{H}_{2} \mathrm{O}_{2}$ might regulate the hexose monophosphate shunt since the latter is controlled by the availability of NADP $(28,29)$. The effects of the addition of NADP and/or GSSG on ${ }^{14} \mathrm{CO}_{2}$ production from glucose- $1-{ }^{14} \mathrm{C}$ were measured in AM homogenates. The data indicate (Table III) that NADP alone causes a $62 \%(P<0.01)$ increase in ${ }^{14} \mathrm{CO}_{2}$ production while GSSG alone causes an insignificant increase. However, GSSG in the presence of NADP causes a further rise in glucose- $1{ }^{14} \mathrm{C}$ oxidation from 162 to $260 \%$ $(P<0.01)$. Cysteine alone or in the presence of NADP had no effect.

The effects of $\mathrm{H}_{2} \mathrm{O}_{2}$ on ${ }^{14} \mathrm{CO}_{2}$ production from glucose- $1-{ }^{14} \mathrm{C}$ were studied employing $\mathrm{DL}$-alanine and purified D-amino acid oxidase (DAAO) as an $\mathrm{H}_{2} \mathrm{O}_{2}$ generating system. The results, Table IV, indicate that, while neither the oxidase nor alanine alone affect $\mathrm{CO}_{2}$ production, their combination stimulates $\mathrm{CO}_{2}$ production nearly fivefold $(P<0.001)$. This increase is inhibited by NEM $(P<0.001)$, suggesting a role for a thiol-containing substance.

Other experiments in which the pyruvate produced from $D$-alanine by this preparation of DAAO was

TABLE III

Effects of NADP and GSSG on ${ }^{14} \mathrm{CO}_{2}$ Production from Glucose-1 $1{ }^{14} \mathrm{C}$

\begin{tabular}{|c|c|c|c|}
\hline Addi & itions to flasks* & $\mathrm{n} \ddagger$ & $\begin{array}{c}\% \text { of control } \\
\text { 土SEM }\end{array}$ \\
\hline \multicolumn{3}{|l|}{ Homogenate } & 100 \\
\hline$"$ & + NADP & 6 & $162 \pm 5$ \\
\hline$"$ & + GSSG & 4 & $115 \pm 16$ \\
\hline$"$ & + NADP + GSSG & 6 & $260 \pm 8$ \\
\hline$"$ & + cysteine & 2 & $120 \pm 27$ \\
\hline$"$ & + NADP + cysteine & 2 & $179 \pm 9$ \\
\hline
\end{tabular}

* Incubations were performed as described under Methods. The concentrations of compounds added to the homogenate were : $0.03 \mathrm{~mm}$ NADP, $30 \mathrm{~mm}$ GSSG, and $15 \mathrm{~mm}$ cysteine. $\ddagger \mathrm{n}$, number of experiments. measured as the 2,4-dinitrophenylhydrazone by the "direct" method of Friedman and Haugen (30) showed no inhibition by concentrations of NEM up to 0.5 mmole/liter. Thus, the observed inhibition by NEM of ${ }^{14} \mathrm{CO}_{2}$ production from glucose-1 $1{ }^{14} \mathrm{C}$ by $\mathrm{AM}$ homogenates in the presence of DL-alanine and DAAO cannot be ascribed to an inhibition of DAAO.

Glucose oxidation and GSH levels during phagocytosis. The preceding evidence indicates that the $\mathrm{H}_{2} \mathrm{O}_{2}$-stimulated oxidation of glucose- $1{ }^{14} \mathrm{C}$ can be mediated by the glutathione reductase and peroxidase enzyme systems. The next studies were designed to determine whether this sequence occurs in the intact AM during phagocytosis. The levels of GSH were measured in extracts of $\mathrm{AM}$ after incubation for various periods of time $(2,5,15$, and $60 \mathrm{~min})$ in the presence of test particles ( $S$. albus or latex). Reproducible significant differences between the levels of GSH in extracts of resting and phagocytosing $\mathrm{AM}$ were not observed. We therefore employed the cell-penetrating thiol inhibitor, NEM, which is known to bind intracellular GSH (31).

The effects of increasing concentrations of NEM on GSH levels and glucose oxidation were examined. These data indicate a progressive fall in GSH levels in resting AM (Fig. 1) as the NEM concentration were increased. At any given NEM concentration, there were no significant differences between intracellular GSH content in resting and phagocytosing AM as indicated by Fig. 1. The control values (no NEM present) for GSH in the AM in the presence or absence of killed $S$. albus were lower than the level reported in Table II. In these experiments, which were designed for correlation with the data on ${ }^{14} \mathrm{CO}_{2}$ production from glucose $-{ }^{14} \mathrm{C}$, the incubation volume was $4 \mathrm{ml}$ (approximately 7.5 million cells $/ \mathrm{ml}$ ). After the incubation, the

TABLE IV

Effects of an $\mathrm{H}_{2} \mathrm{O}_{2}$-Generating System on Glucose-1-14C Oxidation

\begin{tabular}{|c|c|c|c|}
\hline & Additions* & nf & $\begin{array}{c}\% \text { of } \\
\text { control } \\
\pm \text { SEM }\end{array}$ \\
\hline \multicolumn{2}{|l|}{ Homogenate } & 5 & 100 \\
\hline 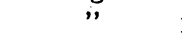 & DL-alanine & 5 & $101 \pm 10$ \\
\hline$"$ & + DAAO & 5 & $98 \pm 9$ \\
\hline$"$ & + DL-alanine + DAAO & 5 & $476 \pm 79$ \\
\hline$"$ & $+\mathrm{NEM}$ & 5 & $44 \pm 8$ \\
\hline$"$ & + DL-alanine & & \\
\hline & $+\mathrm{DAAO}+\mathrm{NEM}$ & 5 & $104 \pm 22$ \\
\hline
\end{tabular}

* Experimental conditions were as indicated under Methods. The concentrations of compounds added to the homogenate were $37.5 \mathrm{~mm}$ DL-alanine, $50 \mu \mathrm{g}$ DAAO, $0.04 \mathrm{~mm}$ NEM. $\ddagger \mathrm{n}$, number of experiments. 


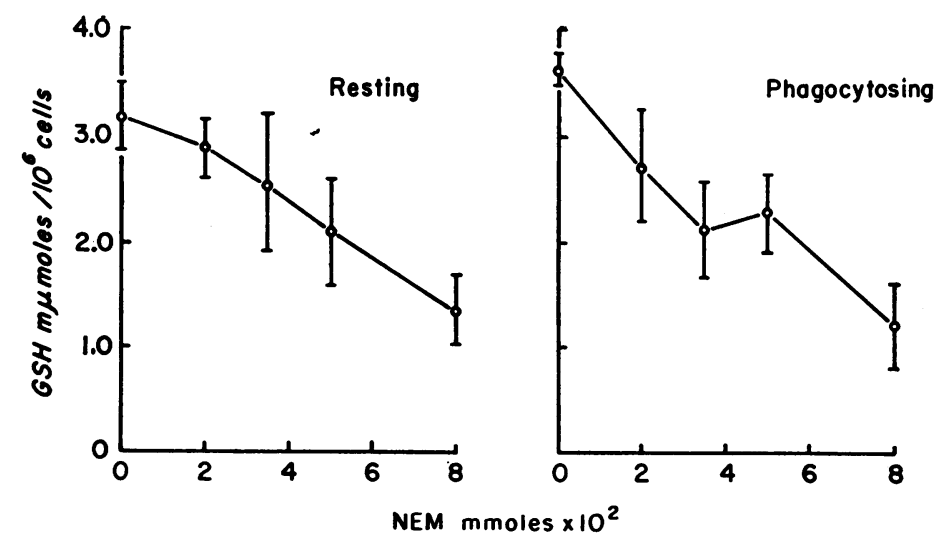

FIGURE 1 The effects of NEM on GSH content in resting and phagocytosing AM. Average of four determinations, vertical bars indicate SEM. Incubation conditions were the same as those for ${ }^{14} \mathrm{CO}_{2}$ production from glucose $-{ }^{14} \mathrm{C}$, total volume, $4 \mathrm{ml}$. After incubation, the cells were sedimented, and resuspended in $1 \mathrm{ml}$ of $0.10 \mathrm{M}$ phosphate, $\mathrm{pH} 6.8$ and GSH determined as described in Methods.

AM were reisolated by centrifugation and resuspended in $1 \mathrm{ml}$ before GSH assay. In experiments not reported here, the difference in levels of GSH in the AM ( $c f$. Table II and Fig. 1) could be accounted for by leakage of both GSH (up to $36 \%$ of total) and GSSG (5\%) from the cells into the supernatant fluid. In this respect, AM differ from red cells since Srivasta and Beutler (32) have shown that only GSSG is transported out of red cells. The effects of NEM on ${ }^{14} \mathrm{CO}_{2}$ production from labeled glucose are shown in Fig. 2. There are striking diminutions in the ${ }^{14} \mathrm{CO}_{2}$ production from both forms of labeled glucose in phagocytosing AM. This contrasts with the effects of NEM on resting
$\mathrm{AM}$ where ${ }^{14} \mathrm{CO}_{2}$ production from glucose- $1{ }^{14} \mathrm{C}$ is virtually unaffected while there is a diminution of ${ }^{14} \mathrm{CO}_{2}$ formation from glucose- $6-{ }^{14} \mathrm{C}$.

The inhibition of glucose oxidation by NEM during phagocytosis may have been due to the specific binding of intracellular GSH, the inhibition of thiol-containing enzymes of the glutathione enzyme system, or to nonspecific binding to any or all of the other thiol-containing cellular proteins.

Evidence supporting the first possibility has been presented in Fig. 1. The activities of GSH peroxidase and GSSG reductase in the presence of the same range of NEM concentration are shown in Fig. 3, which in-
GLUCOSE $-1-{ }^{14} \mathrm{C}$

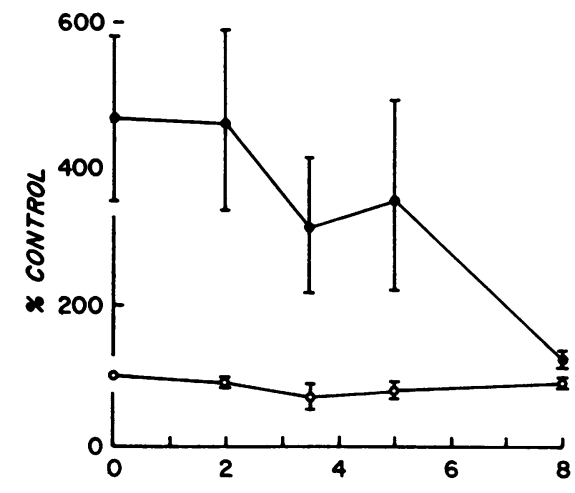

GLUCOSE $-6-{ }^{14} \mathrm{C}$

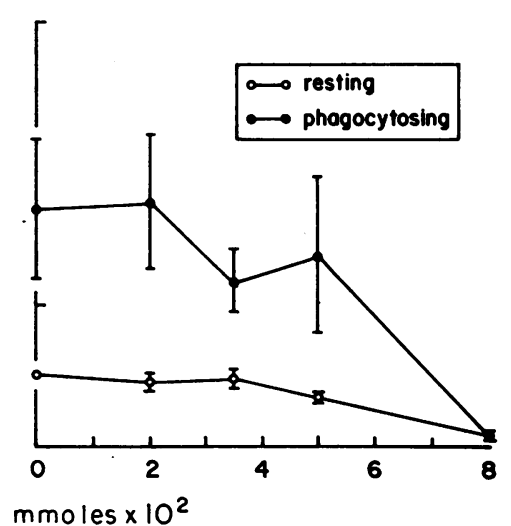

Figure 2 The effects of $\mathrm{NEM}$ on ${ }^{14} \mathrm{CO}_{2}$ production from glucose-1-14 $\mathrm{C}$ (left panel) and glucose-6 $6{ }^{14} \mathrm{C}$ (right panel) in resting (open circles) and phagocytosing (closed circles) AM. Data are expressed as per cent of control resting values in the absence of NEM. Average of four experiments, vertical bars indicate SEM. 


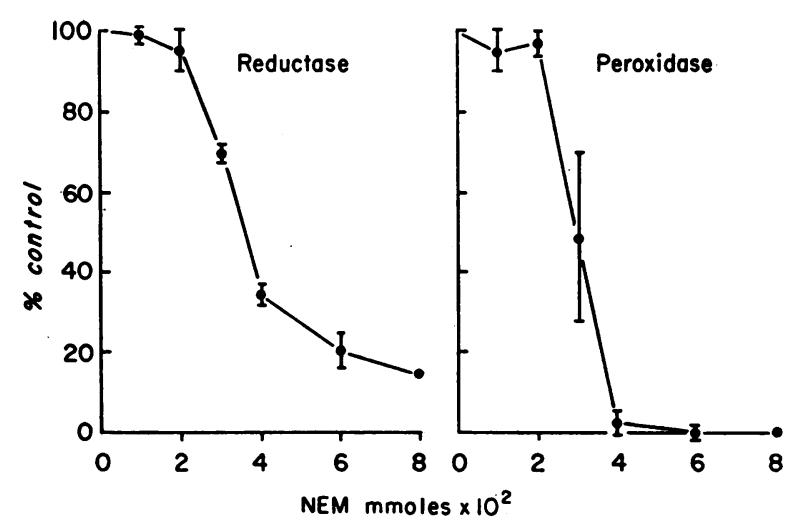

FIGURE 3 GSSG reductase and GSH peroxidase inhibition by NEM. AM were incubated in KRPS in the presence and absence of the indicated concentrations of NEM for $1 \mathrm{hr}$ at $37^{\circ} \mathrm{C}$. The suspensions were centrifuged at $1085 \mathrm{~g}$ for $10 \mathrm{~min}$ in the SS34 rotor of a Sorvall centrifuge. After the centrifuge tubes were drained, $1 \mathrm{ml}$ of $0.067 \mathrm{M}$ phosphate buffer $\mathrm{pH} 7$ was added. Cell lysis and enzyme determinations were performed as indicated in Methods. Average of three determinations, vertical bars indicate SEM.

dicates that both enzymes are inhibited $50 \%$ by preincubation of intact $\mathrm{AM}$ in the presence of $0.03-0.035$ mM NEM.

Further experiments were designed to assess the relative importance of the other thiol groups, e.g., those in the cell membrane and in enzymes not involved in the glutathione system.

First, the effect of a blockade of cell membrane thiol groups by the nonpenetrating inhibitor, $p$-chloromer- curibenzene sulphonic acid ( $\mathrm{pCMBS}$ ), on GSH levels and ${ }^{14} \mathrm{CO}_{3}$ production from glucose were measured. These results (Fig. 4) indicated a different response to that produced by NEM. Glucose conversion to $\mathrm{CO}_{2}$ was diminished only at concentrations of pCMBS $(0.15$ mmole/liter or above) which also produced considerable reduction in cell viability, as judged by rapid staining by eosin. The intracellular GSH content of resting $\mathrm{AM}$ was unaffected by $\mathrm{pCMBS}$ in concentrations below $0.1 \mathrm{mmole} / \mathrm{liter}$. Thus, binding of external membrane thiol groups does not appear responsible for the effect of NEM on glucose oxidation.

Second, the effects of the two thiol inhibitors on particle entry were assessed, since diminished particle entry could explain the decrease in glucose oxidation. While these measurements (Table V) are only semiquantitative, they showed no major impairment of particle entry in the presence of either pCMBS or NEM at concentrations below $0.15 \mathrm{mmole} / \mathrm{liter}$.

Third, NEM might interfere with $\mathrm{H}_{2} \mathrm{O}_{2}$ production in the face of normal particle entry. However, NEM did not affect the catalase-dependent $\mathrm{H}_{2} \mathrm{O}_{2}$ metabolism (Table VI) as judged by ${ }^{14} \mathrm{CO}_{2}$ production from labeled formate (3) even at an NEM concentration $(0.1 \mathrm{mmole} /$ liter) in excess of that which diminished glucose oxidation. Further, employing the catalase inhibitor aminotriazole (AT), it is possible to demonstrate that NEM increases the concentration of $\mathrm{H}_{2} \mathrm{O}_{2}$ in the intact $\mathrm{AM}$. The data in Table VII indicate that NEM increases the inhibition of catalase activity by AT. This increase in catalase sensitivity to AT has been previously shown

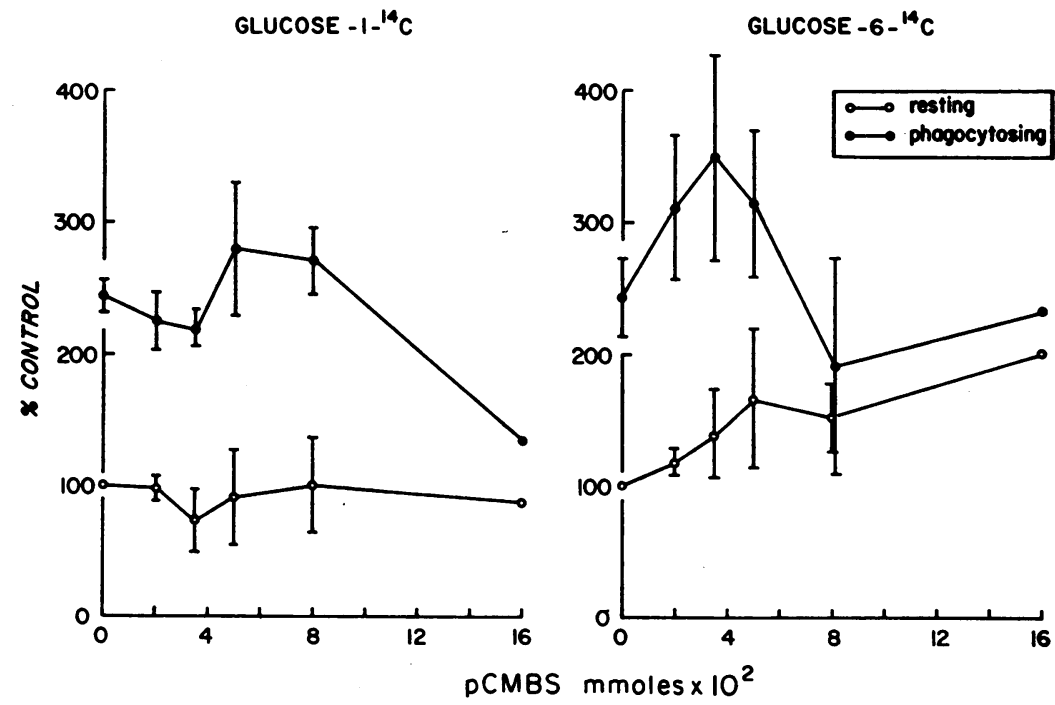

Figure 4 The effects of pCMBS on ${ }^{14} \mathrm{CO}_{2}$ production. Glucose-1- ${ }^{14} \mathrm{C}$ (left panel) and glucose- $6{ }^{14} \mathrm{C}$ (right panel) in resting (open circles) and phagocytosing (closed circles) AM. Data are expressed as per cent of control resting values. Average of five experiments, vertical bars indicate SEM. 
to be due to an increase in the fraction of total catalase existing as catalase: $\mathrm{H}_{2} \mathrm{O}_{2}$ compound 1 as opposed to free catalase $(3,33)$.

Finally, the possibility that NEM might inhibit some enzyme(s) directly involved in glucose oxidation, e.g., glucose-6-phosphate dehydrogenase (34), was considered. However, the stimulatory action of menadiol diphosphate on ${ }^{14} \mathrm{CO}_{2}$ production from glucose- $1-{ }^{14} \mathrm{C}$ by intact AM was unimpaired by $0.1 \mathrm{~mm}$ NEM (Table VIII). Since menadiol acts as an electron acceptor for the oxidation of reduced pyridine nucleotides, the effectiveness of menadiol in the presence of these concentrations of NEM suggests that the glutathione system is more critically affected by NEM than are the enzymes involved in glucose oxidation. Further evidence supporting the glutathione system as an important site of action of NEM is presented in Table IX. While NEM produced a substantial inhibition of glucose oxidation by AM homogenates, partial to complete reversal of this inhibition can be effected by increasing NADP concentration.

\section{DISCUSSION}

The metabolic responses by rabbit AM during phagocytosis include increases in $\mathrm{Q}_{2}$, in ${ }^{14} \mathrm{CO}_{2}$ production from labeled glucose $(2,3)$, and increased $\mathrm{H}_{2} \mathrm{O}_{2}$ formation (3). As indicated in the introduction, the AM are virtually obligatory aerobes and a major fraction of their resting $\mathrm{Qo}_{2}$ is cytochrome dependent $(2,15,16)$. However it is equally clear that $\mathrm{H}_{2} \mathrm{O}_{2}$ is formed by resting and phagocytosing AM (3). The extreme sensitivity of the AM to inhibitors of oxidative phosphorylation limits studies of the metabolic responses to phagocytosis in the presence of such inhibitors, including cyanide. We have therefore approached peroxidative metabolism in the AM by direct measurements of the systems potentially involved.

TABLE V

Effect of Thiol Inhibitors on Bacterial Entry

\begin{tabular}{ccrccc}
\hline & & \multicolumn{4}{c}{$\begin{array}{c}\text { Number of AM containing the } \\
\text { indicated range of particles }\end{array}$} \\
\cline { 3 - 6 } $\begin{array}{c}\text { Bacteria } \\
\text { per cell }\end{array}$ & Exp. & Control & pCMBS & Control & NEM \\
\hline $1-5$ & 1 & 10 & 9 & 14 & 10 \\
& 2 & 7 & 12 & 10 & 12 \\
$6-10$ & 1 & 29 & 31 & 23 & 25 \\
& 2 & 31 & 27 & 26 & 27 \\
$>11$ & 1 & 11 & 10 & 13 & 15 \\
& 2 & 12 & 11 & 14 & 11 \\
\hline
\end{tabular}

50 cells were examined in two sets of paired experiments for each inhibitor. $\mathrm{pCMBS}=p$-chloromercuribenzene sulfonate (0.1 mmole/liter), NEM $=N$-ethylmaleimide $(0.08 \mathrm{mmole} /$ liter), bacteria to cell ratio $25: 1$.
TABLE VI

${ }^{14} \mathrm{CO}_{2}$ Production from Formate- ${ }^{14} \mathrm{C}$

\begin{tabular}{cll}
\hline & Resting & Phagocytosing \\
\hline & \% of conirol & \% of control \\
Control & 100 & $168 \pm 18$ \\
$"+$ NEM & $143 \pm 24^{*}$ & $163 \pm 21$ \\
\hline
\end{tabular}

Mean ISEM for five experiments are indicated. NEM, 0.1 mmole/liter.

* This value not different from control, $P>0.05$.

Glutathione system. The presence of GSH, GSH peroxidase, and GSSG reductase in the AM suggest that the pathways linking noncytochrome oxygen uptake, $\mathrm{H}_{2} \mathrm{O}_{2}$ production, and glucose oxidation take the form indicated in Fig. 5. This scheme is similar to that originally proposed by Reed (12) for rat PMN. Further evidence for the proposal derives from the potentiation by GSSG of NADP-stimulated glucose conversion to $\mathrm{CO}_{2}$ (Table III). The scheme is consistent with the effects of an $\mathrm{H}_{2} \mathrm{O}_{2}$-generating system on glucose oxidation and the inhibition of $\mathrm{H}_{2} \mathrm{O}_{2}$-stimulated $\mathrm{CO}_{2}$ production from glucose by NEM (Table IV). Further, the specific activities of GSH peroxidase and GSSG reductase (20 and $2.6 \mathrm{~m} \mu \mathrm{moles} / \mathrm{min}$ per $10^{8}$ cells) are sufficiently high to explain the noncytochrome $\mathrm{O}_{2}$ uptake since they are compatible with the total rates of oxygen uptake and ${ }^{14} \mathrm{CO}_{2}$ production from $\mathrm{C}_{1}$ - and $\mathrm{C}_{8}$-labeled glucose (2.6 m $\mu$ moles $\mathrm{O}_{2} / \mathrm{min}$ per $10^{6}$ cells, $0.04 \mathrm{~m} \mu$ moles $\mathrm{CO}_{2} / \mathrm{min}$ per $10^{8}$ cells, and $7 \mu$ moles $\mathrm{CO}_{2} / \mathrm{min}$ per $10^{8}$ cells respectively) (3), measured with whole resting cells at $37^{\circ} \mathrm{C}$.

The evidence that the GSH system exists and that it can quantitatively explain these metabolic responses is clear. The direct demonstration of an obligatory requirement for the system is less secure since binding of $\mathrm{GSH}$ or the $\mathrm{SH}$ groups of the enzymes of the glutathione system in an entirely specific fashion is not possible. The observations that NEM diminishes the ${ }^{14} \mathrm{CO}_{2}$ production from labeled glucose without either gross effects on particle entry (Table V) or diminution of catalase-dependent $\mathrm{H}_{2} \mathrm{O}_{2}$ metabolism (Tables VI and VII) is con-

TABLE VII

The Effects of Aminotriazole on Catalase Activity in the Presence of NEM

\begin{tabular}{cccc}
\hline Control & NEM & AT & NEM + AT \\
\hline $0.78 \pm 0.08$ & $0.71 \pm 0.10$ & $0.33 \pm 0.07$ & 0.00 \\
\hline
\end{tabular}

Aliquots from the same AM suspension were incubated under the indicated conditions for $30 \mathrm{~min}$ in KRPS before freezethawing and catalase assay as previously described (3). 0.04 mM NEM, $20 \mathrm{~mm}$ aminotriazole (AT). Mean $\pm \mathrm{SE}$ of three duplicate experiments are indicated. Catalase activity expressed as milliequivalents of perborate utilized in $5 \mathrm{~min}$ (3). 
TABLE VIII

${ }^{14} \mathrm{CO}_{2}$ Production from Glucose- $1-{ }^{14} \mathrm{C}$

\begin{tabular}{cc}
\hline & \% of control \\
\hline Cells & 100 \\
$" \quad+$ menadiol & $250 \pm 21$ \\
$" \quad+$ NEM & $73 \pm 12$ \\
$" \quad+$ menadiol + NEM & $270 \pm 21$
\end{tabular}

Mean ISEM for three experiments are indicated. $0.5 \mathrm{mM}$ menadiol, $0.1 \mathrm{~mm}$ NEM.

sistent with the glutathione system serving as a shuttle between phagocytosis-stimulated $\mathrm{H}_{2} \mathrm{O}_{2}$ production and $\mathrm{NADPH}$-regulated $\mathrm{CO}_{2}$ production from glucose.

As indicated earlier, other possible explanations for the action(s) of NEM have been considered. First, an action of NEM on external membrane $\mathrm{SH}$ groups seems excluded by the dissimilarity between the effects of NEM and pCMBS on glucose metabolism. Second, NEM is known to inhibit the sulfhydryl-containing enzyme glucose-6-phosphate dehydrogenase (34). Therefore, the possibility that NEM partially inhibits glucose oxidation enzymes and so accounts for the inhibition by NEM of ${ }^{14} \mathrm{CO}_{2}$ production from labeled glucose (Fig. 2) remains a real one, particularly at NEM concentrations of $0.1 \mathrm{mmole} / \mathrm{liter}$ or above. However, there are several reasons for ascribing the major effects on glucose oxidation to inhibition of the glutathione system by NEM, particularly at concentrations of $<0.1 \mathrm{mmole} /$ liter. $60 \%$ of GSH is bound at $0.08 \mathrm{~mm}$ NEM (Fig. 1). GSSG reductase is $80 \%$ inhibited at $0.08 \mathrm{mmole} / \mathrm{liter}$ and GSH peroxidase is completely inhibited at 0.04-0.06 mM NEM (Fig. 3). These effects of NEM on the glutathione system, particularly on GSH peroxidase, should be contrasted with the reversibility of the NEM inhibition of ${ }^{14} \mathrm{CO}_{2}$ production from glucose- $1-{ }^{14} \mathrm{C}$ by procedures which increase the NADP: NADPH ratio. In the intact AM, the artificial electron acceptor, menadiol, stimulates glucose oxidation equally in the presence or absence of $0.1 \mathrm{~mm}$ NEM (Table VIII). In the AM homogenate,
TABLE IX

Effects of $\mathrm{NEM}$ and $\mathrm{NADP}$ on ${ }^{14} \mathrm{CO}_{2}$ Production from Glucose-1 ${ }^{14} \mathrm{C}$

\begin{tabular}{lcccc}
\hline & & \multicolumn{3}{c}{ NADP } \\
\cline { 3 - 5 } & & $0.03 \mathrm{mM}$ & $0.3 \mathrm{mM}$ & $0.6 \mathrm{mM}$ \\
\hline No NEM & 100 & $213 \pm 48$ & $398 \pm 137$ & $561 \pm 220$ \\
+ NEM & $23 \pm 8$ & $106 \pm 33$ & $401 \pm 190$ & $650 \pm 306$ \\
\hline
\end{tabular}

AM aliquots were incubated at $37^{\circ} \mathrm{C}$ in KRPS-glucose in the presence or absence of $0.1 \mathrm{mM}$ NEM for $1 \mathrm{hr}$, centrifuged at $480 \mathrm{~g}$ in Sorvall centrifuge at $4^{\circ} \mathrm{C}$ (SS34 rotor) for $10 \mathrm{~min}$. The cell pellet was resuspended in 3 volumes of KRPS, recentrifuged, and pellet resuspended in $9 \mathrm{ml}$ of KRPS before homogenization and measurement of ${ }^{14} \mathrm{CO}_{2}$ production as described under Methods. Data are expressed as per cent of control; mean 土SE of four internally controlled experiments are indicated.

NADP additions can partially or completely reverse the inhibition of glucose oxidation by $0.1 \mathrm{~mm}$ NEM (Table IX). Thus, while a complete analysis of the factors controlling the pentose shunt and glycolysis in the AM is beyond the scope of this paper, our studies provide evidence first that the glutathione system exerts an important influence on glucose oxidation and second that NEM exerts a major effect on the glutathione system at concentrations below $0.1 \mathrm{mmole} / \mathrm{liter}$.

The hypothetical scheme presented in Fig. 5 seems justified by the foregoing evidence. It is similar to $\mathrm{H}_{2} \mathrm{O}_{2}$ utilization pathways described in PMN (12-14) with the exception that GSH peroxidase activity could not be detected by Baehner, Gilman, and Karnovsky (14). However, the latter authors do report a rapid nonenzymatic oxidation of $\mathrm{GSH}$ by $\mathrm{H}_{2} \mathrm{O}_{2}$. The scheme also has analogies with red cells (34), liver (35), and thyroid tissue (36). A number of additional comments are relevant. First, the relative importance of glutathione- and catalase-dependent $\mathrm{H}_{2} \mathrm{O}_{2}$ metabolism (3) is uncertain but the latter, as judged by formate oxidation (3) is much smaller than the stimulation of either $\mathrm{Q}_{o_{2}}$ or glucose oxi-

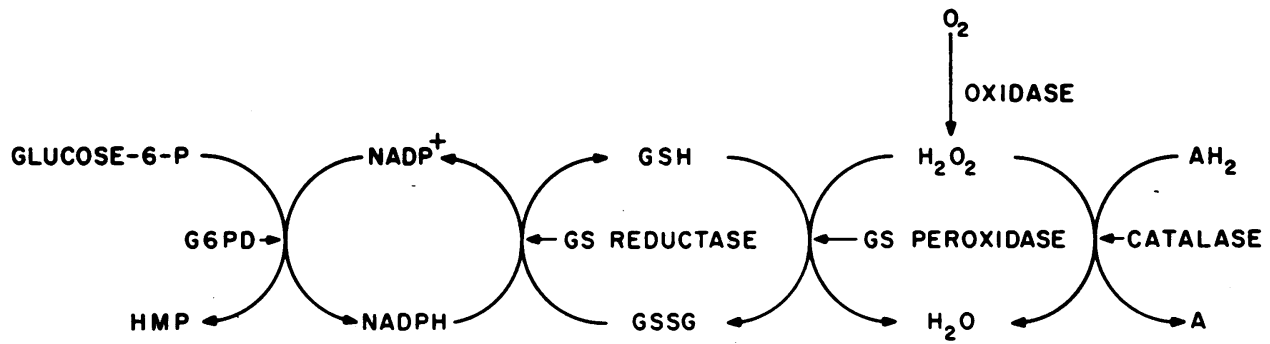

FIGURE 5 Peroxidative metabolic pathways. GSH = reduced glutathione; GSSG= oxidized glutathione; G6PD = glucose-6-phosphate dehydrogenase; HMP = hexose monophosphate shunt; $\mathrm{AH}_{2}$ represents unknown hydrogen donors for catalase. GS reductase and GS peroxidase refer to glutathione enzymes. 
dation during phagocytosis. Second, phagocytosis by PMN is accompanied by striking increases in the oxidation of glucose- $1-{ }^{14} \mathrm{C}$ as opposed to glucose- $6-{ }^{14} \mathrm{C}$ presumably via the hexose monophosphate shunt (4-6). However, the rabbit AM responds to phagocytosis with smaller pari passu increases in ${ }^{14} \mathrm{CO}_{2}$ production from both glucose-1 ${ }^{14} \mathrm{C}$ and glucose- $6-{ }^{14} \mathrm{C}(2,3)$. These differences may derive from the combination of a pyridine nucleotide transhydrogenase (Table I) and numerous mitochondria in the AM (17).

$\mathrm{H}_{2} \mathrm{O}$, generation. Our previous studies (3) indicated that AM peroxidative metabolism was stimulated by phagocytosis of heat-killed $S$. albus as judged by increased formate oxidation, increases in the fraction of intracellular catalase existing as catalase: $\mathrm{H}_{2} \mathrm{O}_{2}$ compound 1 and increased $\mathrm{H}_{2} \mathrm{O}_{2}$ present in the dialysate from phagocytosing AM. A recent study by Paul, Strauss, Jacobs, and Sbarra (37) failed to show increases in $\mathrm{H}_{2} \mathrm{O}_{2}$ in rabbit AM dialysates during phagocytosis of killed $E$. coli. The reason for this discrepancy is not clear. However both studies demonstrate $\mathrm{H}_{2} \mathrm{O}_{2}$ to be present in the 45-min dialysates from resting $\mathrm{AM}$, namely 0.59 m $\mu$ moles $/ 10^{\circ} \mathrm{AM}$ (37) and $0.1-0.15 \mathrm{~m} \mu$ moles $/ 10^{\circ} \mathrm{AM}$ (3).

The present studies provide some limited information on the source of $\mathrm{H}_{2} \mathrm{O}_{2}$. D-Amino acid oxidase activity has been demonstrated with $\mathrm{D}$-alanine as substrate. The potential role of this enzyme as an antibacterial agent has recently been suggested by Cline and Lehrer (11) who also indicate the difficulties of ascribing all phagocytosis-stimulated $\mathrm{H}_{2} \mathrm{O}_{2}$ formation to this enzyme in view of its specificity for D-isomers. This difficulty is accentuated by the fact that both $Q_{o_{2}}$ and glucose oxidation increase during the phagocytosis of latex particles by $\mathrm{AM}^{2}{ }^{2}$ In spite of the use of a wide range of experimental conditions no cyanide-insensitive pyridine nucleotide oxidase activity could be detected.

Significance of the glutathione system. The potential role of glutathione as either an anti-oxidant or a prooxidant, depending on the experimental conditions, has been discussed for many years and recently reviewed $(38,39)$. Our data indicate the role of the glutathione system as an intracellular anti-oxidant with respect to $\mathrm{H}_{2} \mathrm{O}_{2}$ especially during phagocytosis. It is reasonable to suggest the possibility that glutathione serves a more general anti-oxidant role in protecting the AM, a cell of critical importance in the pulmonary response to inhaled particles including microorganisms (40). This hypothesis is suggested by the two main considerations. First, radiation, ozone, high $\mathrm{O}_{2}$ tensions $(38,39)$, and nitrogen dioxide (41) all generate highly injurious lipid peroxides, which, inter alia, diminish lysozomal stability (42).

\footnotetext{
${ }^{2}$ Vogt, M., R. E. Basford, and J. B. L. Gee. Unpublished observations.
}

Second, the AM possess vigorous GSH peroxidase activity and this enzyme can detoxify lipid peroxides in other biologic systems $(43,44)$.

\section{ACKNOWLEDGMENTS}

The skilled technical assistance of Mr. Richard W. Bell and Miss Joan Yogodnik is gratefully acknowledged.

This work was supported in part by Grant IRO1 UI00850 from the National Institutes of Health, U. S. Public Health Service, and in part by grants from the Health Research and Services Foundation.

\section{REFERENCES}

1. Gee, J. B. L., and R. E. Basford. 1969. The effects of sulfhydryl inhibitors on phagocytosis by alveolar macrophages. Fed. Proc. 28: 445.

2. Ouchi, E., R. J. Selvaraj, and A. J. Sbarra. 1965. The biochemical activities of rabbit alveolar macrophages during phagocytosis. Exp. Cell Res. 40: 456.

3. Gee, J. B. L., C. L. Vassallo, P. Bell, J. Kaskin, R. E. Basford, and J. B. Field. 1970. Catalase-dependent peroxidative metabolism in the alveolar macrophage during phagocytosis. J. Clin. Invest. 49: 1280.

4. Sbarra, A. J., and M. L. Karnovsky. 1959. The biochemical basis of phagocytosis. I. Metabolic changes during the ingestion of the particles by polymorphonuclear leucocytes. J. Biol. Chem. 234: 1355.

5. Iver, G. Y. N., M. F. Islam, and J. H. Quastel. 1961. Biochemical aspects of phagocytosis. Nature (London). 192: 535.

6. Karnovsky, M. L. 1962. Metabolic basis of phagocytic activity. Physiol. Rev. $42: 143$.

7. Cagan, R. H., and M. L. Karnovsky. 1964. Enzymatic basis of the respiratory stimulation during phagocytosis. Nature (London). 204: 255.

8. Iver, G. Y. N., and J. H. Quastel. 1963. Reduced nicotineamide adenine dinucleotide phosphate and reduced nicotineamide adenine dinucleotide oxidation by guinea pig polymorphonuclear leucocytes. Can. J. Biochem. Physiol. 41 : 427.

9. Zatti, M., and F. Rossi. 1966. Mechanism of the respiratory stimulation in phagocytosing leucocytes. The KCNinsensitive oxidation of $\mathrm{NADPH}_{2}$. Experientia. 22: 758.

10. Roberts, J., and J. H. Quastel. 1964. Oxidation of reduced triphosphopyridine nucleotide by guinea pig polymorphonuclear leucocytes. Nature (London). 202: 85.

11. Cline, M. J., and R. I. Lehrer. 1969. D-amino acid oxidase in leucocytes: a possible D-amino acid linked antimicrobial system. Proc. Nat. Acad. Sci. U. S. A. $62: 756$.

12. Reed, P. W., 1969. Glutathione and the hexose monophosphate shunt in phagocytizing and hydrogen peroxidetreated rat leucocytes. J. Biol. Chem. 244: 2459.

13. Strauss, R. R., B. B. Paul, A. A. Jacobs, and A. J. Sbarra. 1969. The role of the phagocyte in host-parasite interactions. XIX Leucocytic glutathione reductase and its involvement in phagocytosis. Arch. Biochim. Biophys. $135: 265$.

14. Baehner, R. L., N. Gilman, and M. D. Karnovsky. 1970. Respiration and glucose oxidation in human and guinea pig leucocytes: comparative studies. J. Clin. Invest. 49: 692.

15. Oren, R., A. E. Farnham, K. Saito, E. Milofsky, and M. L. Karnovsky. 1963. The metabolic patterns in three types of phagocytyzing cells. J. Cell. Biol. 17: 487. 
16. Gee, J. B. L., E. D. Robin, J. B. Field, J. D. Smith, A. R. Tanser, and J. Kaskin. 1968. Roles of ATP and peroxidative metabolism during phagocytosis in alveolar macrophages. J. Clin. Invest. 47: 38a. (Abstr.)

17. Policard, A., A. Collet, and S. Pregermain. 1956. Electron microscope studies on alveolar cells from mammals. In European Regional Conference on Electron Microscopy. Proceedings of the Stockholm Conference. F. S. Sjöstrand and J. Rhodin, editors. Academic Press Inc., New York. 244.

18. Horn, H.-D. 1965. Glutathione reductase. In Methods of Enzymatic Analysis. H. U. Bergmeyer, editor. Academic Press Inc., New York. 875.

19. Paglia, D. E., and W. N. Valentine. 1967. Studies on the quantitative and qualitative characterization of erythrocyte glutathione peroxidase. J. Lab. Clin. Med. $70: 158$.

20. Evans, A. E., and N. O. Kaplan. 1966. Pyridine nucleotide transhydrogenase in normal human and leukemic leucocytes. J. Clin. Invest. 45: 1268

21. Cohn, Z. A., and J. G. Hirsch. 1960. The isolation and properties of specific cytoplasmic granules of rabbit polymorphonuclear leucocytes. J. Exp. Med. 112: 983.

22. Dixon, M., and K. Kleppe. 1965. D-Amino acid oxidase. I. Dissociation and recombination of the holoenzyme. Biochim. Biophys. Acta. 96: 357.

23. Löhr, G. W., and H. D. Waller. 1965. Glucose-6-phosphate dehydrogenase. In Methods of Enzymatic Analysis. H. U. Bergmeyer, editor. Academic Press Inc., New York. 744.

24. Beutler, E. 1957. The glutathione instability of drugsensitive red cells. A new method for the in vitro detection of drug sensitivity. J. Lab. Clin. Med. 49: 84 .

25. Klotzsch, H., and H. U. Bergmeyer. 1965. Glutathione. In Methods of Enzymatic Analysis. H. U. Bergmeyer, editor. Academic Press Inc., New York, 363.

26. Toennies, G., and J. J. Kolb 1951. Techniques and reagents for paper chromatography. Anal. Chem. 23: 823.

27. Melville, D. B. 1959. Ergothioneine. Vitamins Hormones. $17: 155$.

28. Cahill, G. F., Jr., A. B. Hastings, J. Ashmore, and S. Zottu. 1958. Studies on carbohydrate metabolism in rat liver slices. X. Factors in the regulation of pathways of glucose metabolism. J. Biol. Chem. 230: 125.

29. Beck, W. S. 1958. The control of leucocyte glycolysis. $J$. Biol. Chem. 232: 251.
30. Friedemann, T. E., and G. E. Haugen. 1943. Pyruvic acid. II. The determination of keto acids in blood and urine. J. Biol. Chem. 147: 415.

31. Webb, J. L. 1966. Enzyme and Metabolic Inhibitors. Academic Press Inc., New York. Vol. 3. 361

32. Srivastava, S. K., and E. Beutler. 1969. The transport of oxidized glutathione from human erythrocytes. J. Biol. Chem. 244: 9.

33. Margoliash, E., and A. Novogrodsky. 1958. A study of the inhibition of catalase by 3 -amino-1:2:4 triazole. Biochem. J. 68: 468.

34. Jacob, H. S., and J. H. Jandl. 1966. Effects of sulfhydryl inhibition on red blood cells. III. Glutathione in the regulation of the hexose monophosphate pathway. $J$. Biol. Chem. 241: 4243.

35. Hochstein, P., and H. Utley. 1968. Hydrogen peroxide detoxication by glutathione peroxidase and catalase in rat liver homogenates. Mol. Pharmacol. 4: 574.

36. Benard, B., and L. J. DeGroot. 1969. The role of hydrogen peroxide and glutathione in glucose oxidation by the thyroid. Biochim. Biophys. Acta. 184: 48.

37. Paul, B. B., R. R. Strauss, A. A. Jacobs, and A. J. Sbarra. 1970. Function of $\mathrm{H}_{2} \mathrm{O}_{2}$, myeloperoxidase and hexose monophosphate shunt enzymes in phagocytosing cells from different species. Infection Immunity 1: 338.

38. Haugaard, N. 1968. Cellular mechanisms of oxygen toxicity. Physiol. Rev. 48: 311.

39. Menzel, D. B. 1970. Toxicity of ozone, oxygen and radiation. Annu. Rev. Pharmacol. 10: 379.

40. Green, G. M. 1968. Pulmonary clearance of infectious agents. Annu. Rev. Med. 19: 315.

41. Thomas, H. V., P. K. Mueller, and R. L. Lyman. 1968 Lipoperoxidation of lung lipids in rats exposed to nitrogen dioxide. Science (Washington). 159: 532.

42. Wills, E. D., and A. E. Wilkinson. 1966. Release of enzymes from lysozomes by irradiation and the relation of lipid peroxide formation to enzyme release. Biochem. $J$. 99: 657.

43. Christophersen, B. O. 1968. Formation of monohydroxypolenic fatty acids from lipid peroxides by a glutathione peroxidase. Biochim. Biophys. Acta. 164: 35.

44. O'Brien, P. J., and C. Little. 1969. Intracellular mechanisms for the decomposition of a lipid peroxide. II. Decomposition of a lipid peroxide by subcellular fractions. Can. J. Biochem. 47: 493. 